\title{
The Investigation and Analysis of College Students' Legal Awareness---a Survey with Beijing College Students as Subjects
}

\author{
Lin $\mathrm{LI}^{1, \mathrm{a}}$ \\ ${ }^{1}$ School of Humanities and Economic Management, China University of Geoscience, Beijing, China. \\ School of Marxism, China University of Geoscience, Beijing ,China. \\ alilin@cugb.edu.cn
}

Keywords: College students, right consciousness, investigation.

\begin{abstract}
With the advancement of basic governing strategy of Chinese government, college students care more about their legal rights. In order to improve their teaching ability, colleges and universities must fully realize the legal awareness of the students at present. Based on the survey of students from 5 colleges in Beijing, we found the legal awareness of college students was stronger, especially concerning of their personal rights and interests, including right of equality, the right of justice, rights of privacy, etc.
\end{abstract}

\section{Introduction}

The basic citizen rights of college students are protected by the Constitution and relevant laws and regulations, including the basic political rights such as the right to vote and to be elected, the right of freedom of speech, freedom of religion, the right to live, the right to develop, the right of personal liberty, dignity, the right to work, the right of reputation, the right of privacy and the right of identity (Inheritance right, copyright, right to invention, right to receive education).College students shall enjoy the right to receive education. At the same time they are also special educatees and the higher education service consumers, they have not only the basic right to receive education but also enjoy some special rights, including the right to receive scholarships, grants, poverty loans, the right to get the corresponding qualification certificate and degree certificate.

\section{Subjects and Methods}

The subject of this questionnaire survey was the four-year undergraduate students of five universities in Beijing, who were mainly in grade one, grade two and grade three. 200 questionnaires were issued, 199 were taken back, recovery rate is $99.5 \%$. The qualified questionnaires were 198(99.4\%). The gender distribution of the qualified questionnaires was: male 30. 3\%, female 69.7\%; The grade distribution was: $23.6 \%$ were first-grade students, $31.9 \%$ were second-grade students, while other $44.5 \%$ were third-grade ones. Major distribution: science and engineering students were $48.4 \%$, other majors were $51.6 \%$. The analysis of data was done with SPSS.

\section{The Data of the Survey and Analysis}

\section{Insufficient Understanding of the Legal System}

Only $16.17 \%$ students could name the basic frame work and constitutions of Chinese legal system.46.97\% students hardly knew anything about the legal system of our country(Table 1). According to the data, a large proportion of the students lacked the knowledge of law and understanding of the legal system of our country. They should learn more about legal knowledge and deepen their understanding of the legal system of our country. 
Table 1 The level of understanding of the legal system

\begin{tabular}{|c|c|c|c|c|}
\hline $\begin{array}{c}\text { Understanding of the } \\
\text { legal system }\end{array}$ & I & II & III & IV \\
\hline Percentage & $16.17 \%$ & $22.72 \%$ & $46.97 \%$ & $14.14 \%$ \\
\hline
\end{tabular}

* According to the scores of ten questions concerning legal system knowledge answered by the subjects in the questionnaires, the grouping standards were that level I: correction rate was or higher than 8/10; level II: correction rate was 6/10 8/10; level III: correction rate was 4/10 6/10; level IV: correction rate was under $4 / 10$.

\section{The Knowledge of Law Was Deemed Useless.}

$39.9 \%$ of the college students thought that laws closely related with their study and life. $15.15 \%$ of them considered that laws had nothing to do with their life while other $6.57 \%$ of the students were not sure about the role played by the laws (Table 2). According to data, a large proportion of the college students lacked knowledge of the laws, at the same time who believed that legal knowledge was no use for their everyday life. So, we could jump to the conclusion it was their reluctant study of law knowledge leading to their poor knowledge of the legal system.

Table 2 Law and the relationship between study and life

\begin{tabular}{|c|c|c|c|}
\hline $\begin{array}{c}\text { Closely related and } \\
\text { important }\end{array}$ & $\begin{array}{c}\text { Related but not } \\
\text { important }\end{array}$ & Not related at all & Not sure \\
\hline $39.90 \%$ & $38.38 \%$ & $15.15 \%$ & $6.57 \%$ \\
\hline
\end{tabular}

\section{Legal Approach was not Always Chosen When Legal Rights Violation Took Place.}

When their rights were violated, $21.71 \%$ of the students chose to settle it through interpersonal relation net. $11.11 \%$ of the students choose to solve the problem by violence. $25.76 \%$ of them restrained themselves instead of reacting publicly (Table 3). According to the data, on one hand, college students were able to realize that their rights were protected by laws, on the other hand, they couldn't solve the problems by legal approach. The first step to solve this issue was to deepen the understanding of legal system among college students, and to help them to set up scientific world outlook and values. It also showed the insufficiency of college students' legal awareness and their lack of social responsibility.

Table 3.How to deal with infringements of one’s legal rights

\begin{tabular}{|c|c|c|c|c|}
\hline Type of reaction & Solve it by relation net & Solve it by violence & restraint & $\begin{array}{c}\text { Solve it by legal } \\
\text { approach }\end{array}$ \\
\hline percentage & $21.71 \%$ & $11.11 \%$ & $25.76 \%$ & $41.42 \%$ \\
\hline
\end{tabular}

\section{College Students Lacked Legal Awareness.}

$28.43 \%$ of college students believed that legal system the main function of civic duty; it regulated the behavior of people. And $8.68 \%$ of college students believe that law is to consolidate the ruling class (Table 4). According to data, college students thought that the main purpose of law was not to protect the rights of citizens, but to punish illegal crimes, civic duty definitions and governing power consolidation.

Table 4 The functions of law

\begin{tabular}{|c|c|c|c|}
\hline $\begin{array}{c}\text { To protect the rights of } \\
\text { citizens }\end{array}$ & $\begin{array}{c}\text { Punishment for illegal } \\
\text { crime }\end{array}$ & $\begin{array}{c}\text { definitions of citizen's } \\
\text { obligation }\end{array}$ & $\begin{array}{c}\text { To consolidate the } \\
\text { governing power }\end{array}$ \\
\hline $40.91 \%$ & 21.72 & $28.28 \%$ & $9.09 \%$ \\
\hline
\end{tabular}


When security agents wanted to rummage their carry-on baggage in a mall without warranty, 22.63\% of college students choose tolerant instead of resistance. According to the data, college students were afraid of laws, and distrusted laws (Table 5). Unfortunately, these data showed that college students' legal awareness was insufficient in our country.

Table 5 Suffer from illegal search approach for itself

\begin{tabular}{|c|c|c|}
\hline Refused & $\begin{array}{c}\text { Looking for managers or consumer } \\
\text { service partment to complain }\end{array}$ & tolerance \\
\hline $38.38 \%$ & $38.89 \%$ & $22.73 \%$ \\
\hline
\end{tabular}

\section{Summary and Discussion}

Through investigation, we found that there were three problems waiting to be solved.

\section{The Level of College Students’ Legal Awareness Was Improved}

Generally speaking, college students' legal awareness had been greatly enhanced, but their cognition of rights was still in a relatively lower level. The understanding of legal system of administrators in colleges and universities must improve in order to manage students with more legal knowledge.

\section{What Were Their Concerns about Legal Rights?}

College students cared about their personal interests, such as property rights, personal rights, the right of receiving education, the right of privacy and right of fair evaluation. In order to work better, the managers of colleges should be fully aware of the requirements of the students.

\section{How to Protect Legal Rights When They Were Violated?}

When college students were under infringement, there were many ways to handle the situations. They preferred to solve it by the head of the school instead of seeking help from the judicial department. We needed to establish a better student management system and improve the student right protection system.

\section{Acknowledgement}

This research was financially supported by the capital of college students' ideological and political education research subject.

\section{References}

[1] Ni X-L, Yan H, Chen S-L, et al. Factors Influencing Internet Addiction in a Sample of Freshmen University Students in China. CyberPsychology \& Behavior 2009; 12: 327-330.

[2] Caplan S.E. Relations Among Loneliness, Social Anxiety, and Problematic Internet Use. Cyberpsychology \& behavior 2007; 10:234-242.

[3] Odaci H,Kalkan M. Problematic Internet use, loneliness and dating anxiety among young adult university students.Computers \& Education 2010; 55:1091-1097. 